\title{
Aktiv praksis i hjemmetjenesten
}

\author{
Å lage aktivitetsprogram for eldre brukere av hjemmetjenester \\ $ø$ kte sykepleierstudentenes interesse for eldreomsorg.
}

en årrekke har bydeler og kommuner tatt imot sykepleiestudenter fra Diakonhjemmet Høgskole. I tillegg til konkret studentarbeid har høyskolen hatt samarbeidsprosjekter i noen distrikter for å øke kompetansen både hos personale og studenter. Hjemmesykepleien er i stor grad organisert ut fra en «bestillerutførermodell» med utspring i Publish Management. Til tross for lovpålegg og innsikt i at helsefremmende og forebyggende tiltak blant eldre og kronisk syke må styrkes, har dette ikke blitt prioritert i daglig virksomhet. Det foreligger heller ikke noen plan for hvordan dette reint praktisk skal gjennomføres for brukere av hjemmebaserte tjenester. Dette ville vi gjøre noe med.

\section{Pilotprosjekt}

Ved Diakonhjemmet Høgskole besluttet vi derfor å gjennomføre et pilotprosjekt i studentenes

\section{Hovedbudskap}

Dette samarbeidsprosjektet mellom studenter, lærer og praksisfeltet i kommunehelsetjenesten viser at studenter har mye å bidra med og lære av når de får arbeide selvstendig. Aktiviseringsprosjektet økte studentenes interesse for hjemmesykepleien, og for systematisk kvalitetsutvikling innenfor forebyggende helsearbeid og rehabilitering.

\section{Søkeord}

Les mer og finn litteraturhenvisninger på våre nettsider. \Hemmesykepleie / Forebygging / Livskvalitet > Sykepleierstudent praksisperiode i hjemmebaserte tjenester (1). Ved å delta i prosjektet skulle studentene få opplæring i fagutvikling, forskning, kvalitet og endringsarbeid og forholde seg til politiske føringer og myndighetskrav (2). Metoden var å kartlegge og evaluere pasienters funksjonsnivå og livskvalitet før og etter at de hadde utviklet og gjennomført et aktiviseringsprogram.

Forskning viser at studenter har mye å lære av å ta egne beslutninger (3) og ved å jobbe selvsten$\operatorname{dig}(4,5)$. Studentene fikk derfor frie tøyler til å utarbeide aktiviseringsprogram for sin pasient. De eneste kravene var at det tok utgangspunkt i pasientens individuelle behov, var relevant med tanke på forebygging av inaktivitet blant eldre og kronisk syke, at det var kunnskapsbasert og samstemt med annen behandling.

Aktiviseringsprosjektet var et bidrag til helsefremmende behandling i kommunehelsetjenesten og til økt samarbeid mellom kommunehelsetjenesten og Diakonhjemmet Høgskole i tillegg til at det ga studentene fagutviklingskompetanse. I dette kapittelet vil de helsefremmende aktivitetene bli vektlagt.

\section{Mål og hensikt}

Hensikten med den helsefaglige delen av prosjektet, som denne artikkelen handler om, var å lære sykepleierstudenter opp i tiltak som imøtekommer samfunnets behov for forebygging av inaktivitet og rehabilitering av eldre og kronisk syke. Målet var at brukerne av hjemmebaserte tjenester 1) fikk hjelp til omsorg og rehabilitering og aktivisering ut fra sine ønsker og behov samt 2) oppleve forbedret funksjonsevne og livskvalitet.

\section{Gjennomføring}

Hjemmetjenesten fikk informasjon om prosjektet i semesteret før oppstart. Samarbeid om utforming og drift av prosjektet viste seg å være vanskelig fordi de ansatte mente de ikke hadde tid og rom for slike aktiviteter i hjemmesykepleien. Prosjektet hadde dermed lite forankring i virkeligheten. Men distriktene var positive til at studentene kunne utføre treningsaktiviteter med enkelte brukere på egen hånd, og sa seg villige til å hjelpe studenter med å identifisere egnete kandidater. I tillegg fikk sykepleierne i hjemmetjenesten tilbud om sykepleiefaglig veiledning. Bakgrunnen for dette tilbudet var å tilføre praksisstedet veiledningskunnskaper, samt å fange opp og drøfte eventuelle utfordringer i prosjektet. Studentene fikk informasjon om prosjektet i begynnelsen av hvert semester. Praksisperioden hadde en sterkere vektlegging på kartlegging, aktivisering og evaluering, men var ellers lik en vanlig praksisperiode. De studentene som var interesserte meldte seg på prosjektet.

\section{Kartlegging}

Tjueen studenter i andre studieår og 17 pasienter som var brukere av hjemmebaserte tjenester, ble inkludert i prosjektet på frivillig basis. Pasientenes gjennomsnittsalder var 85 år. På det første møtet mellom pasient og student informerte studenten interesserte pasienter om treningsprogrammet og innhentet samtykke fra dem som ønsket å delta. Pasientene fikk beskjed om at de kunne trekke seg fra opplegget når de måtte ønske det. Praksisperioden i hjemmebaserte tjenester 
$\stackrel{\text { plabogen }}{=}=$

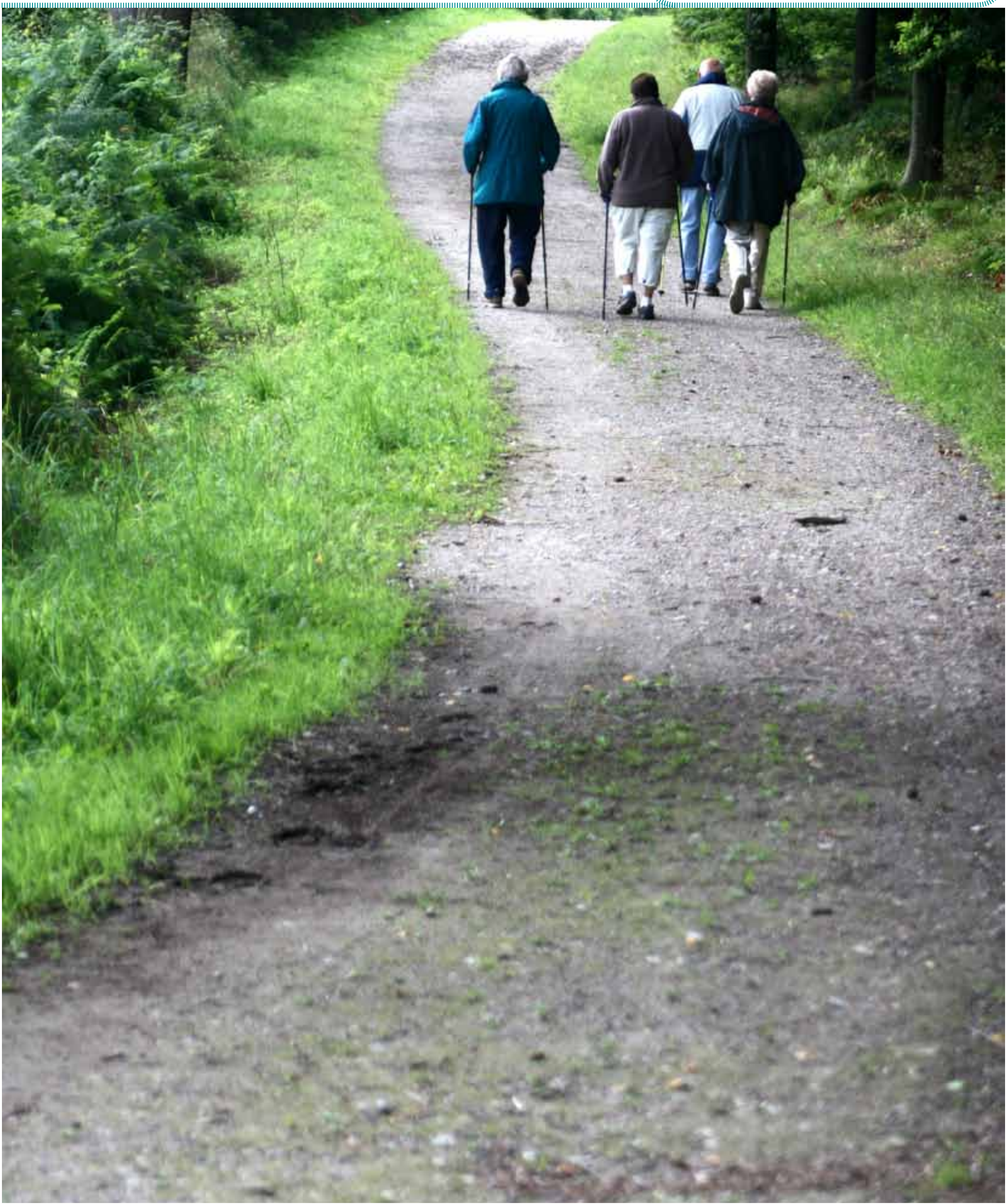


strekker seg over ni uker. Studentene ble derfor oppfordret til å finne en egnet treningskandidat allerede i første praksisuke. Når det var gjort, kartla de pasientenes funksjonsnivå og opplevd livskvalitet ved hjelp av kartleggingsinstrumentene Individuell Pleie og omsorgsstatistikk (IPLOS) (6), Barthel ADL-Index (7) og Verdens helseorganisasjons (WHO) Quality of Life-BREF (8).

\section{Treningsprogram}

Pasientene som deltok i prosjektet fulgte et systematisk treningstilbud. Programmet ble tilrettelagt ut fra brukernes funksjonsnivå, individuelle behov, ønsker og ressurser. Tiltakene ble diskutert med praksisveileder, lærer og tverrfaglig personale. De strakte seg maksimalt over én time to ganger i uken, og var eksempelvis gymnastikk, balanse- og kondisjonstrening, strekkøvelser, trappegang og turgåing. Studentene fikk utdelt kartleggingsskjema, veiledere til utfylling av disse samt eksempler på aktuelle øvelser. Studentene var ansvarlige for å gjennomføre, loggføre og evaluere aktivitetene.

\section{Studentenes erfaringer}

For å kartlegge studentenes erfaringer har jeg benyttet kvalitativ metode (9) med et fenomenologisk og hermeneutisk forskningsdesign.

\section{«Studentene opplevde at de i altfor stor grad var overlatt til seg selv.»}

Jeg anvendte åpne spørsmål for å stimulere studentene til å snakke fritt rundt aktiviseringsprosjektet uten avbrytelser fra prosjektleder. Uttalelser jeg fant spesielt viktige ble fulgt opp. Intervjuene ble tatt opp på lydbånd og transkribert.

\section{Resultater}

Studentene vurderte prosjektet som stimulerende og faglig berikende. De sa blant annet: «det har vært flott å gjøre noe som en selv har tatt initiativ til og har faglig ansvar for. Aktiviseringsprosjektet var en positiv faktor i hverdagen, det var morsomt med øvelsene både for meg og for pasienten».

Studentene syntes praksis i hjemmebaserte tjenester var fragmentert, gjøremålsorientert og styrt av beskjeder og ordrer, og at det derfor var godt å ha noe fast å gå til som de selv kunne utvikle, administrere og ta ansvar for. I tillegg bidro prosjektet til at de fikk helhetsforståelse for pasientenes situasjon og behov. Studentene ble godt kjent med eldre mennesker, de fikk et videre perspektiv på aldring og økt motivasjon til å endre strukturer til pasientens beste. Sykepleiestudentene sa også at de var blitt mer opptatte av trening som forebyggende helsearbeid.

Sykepleierne i praksisfeltet var åpne for nytenkning og selvstendig arbeid. Likevel syntes studentene at det var vanskelig å få gehør for ideer og ønsker. Det krevde mye innsats å si fra om uheldige forhold og komme med nye ideer, spesielt når sykepleierne var travle og lite tilgjengelige. Studentene opplevde at de i altfor stor grad var overlatt til seg selv, at veiledningen var sporadisk og tilfeldig, og de savnet systematisk oppfølging og motivasjon fra sykepleierne. Det var også vanskelig å finne tid og rom for samarbeid med praksisveilederne om treningsaktivitetene.

\section{Program}

Studentene var kreative og uredde i planleggingen og utføringen av treningsprogrammene. De hadde mye personlig kunnskap på området og lite behov for veiledning utover å få det tilpasset brukerens helsebegrensninger og ønsker. De syntes det var morsomt å planlegge og gjennomføre treningsprogram sammen med brukerne og, ikke minst, å se resultater. Studentene understreket at de hadde tid, kunnskap og lyst til å arbeide systematisk og helhetlig for å hjelpe pasienter til å nå mål som var viktige for dem. Flere studenter ga uttrykk for at de ikke kjente seg igjen i den stressende hverdagen som ofte blir beskrevet i media. «Egentlig synes jeg ikke hjemmesykepleierne har så dårlig tid. Det har de som oftest bare når det skjer noe akutt», sa en student. En annen student fortalte om en pasient som etter å ha deltatt i aktiviseringsprosjektet, klarte å gå på toalettet selv i stedet for å bruke dostol. Studenten viste med dette at man sparer tid på å aktivisere pasientene, og at beslutninger om ikke å gjøre det er basert på kortsiktige vurderinger. Studentene var også opptatt av politiske føringer, aktivitetenes betydning og mente studentene alltid bør ta ansvar for og utføre slikt utviklingsarbeid på egen hånd. En student sa at «vi studenter har faktisk en god del tid som vi kan bruke på egen hånd, men vi trenger motivasjon, «et spark bak» for å bruke tiden meningsfullt». Brukerne opplevde omsorg, forbedret funksjonsevne og livskvalitet.

\section{Glade pasienter}

Analysene av datamaterialet, innhentet ved hjelp av Iplos, Barthel og WHO Quality of LifeBREF, viste ikke til statistiske endringer. Fravær i statistiske endringer over tid kan være et positivt funn når det relateres til økende alder, men det kan også skyldes ufullstendige datasett eller at treningsaktivitetene gikk over kortere tid enn anbefalt i litteraturen $(10,11)$. Trass i disse funnene ga studenter uttrykk for at mange av pasientene var blitt gladere, sterkere og mer selvstendige, og at de hadde stor glede av aktivitetene. Flere av pasientene klarte flere repetisjoner av øvelser, fikk mer styrke og ble bedre både funksjonelt og mentalt. En student beskrev en pasients innsats på denne måten: «Pasienten min sa at han var blitt mye mykere, var glad for at han fikk trene, at han så mer positivt på egen helse og framtiden, og trodde selv at han kunne bli bedre». En annen student sa at «pasienten kom seg veldig. Når fysioterapeuten var der gjorde han treningen, men for hennes del. Når pasienten var med meg, gjorde han det uten at jeg måtte mase. Han gjorde det for sin egen del og antakeligvis fordi jeg tok utgangspunkt i et område som var viktig for ham. Pasienten fikk gå der han hadde lyst til å gå. Han var svært motivert for å se en byggeplass i nærheten, og å se bakgården i sitt eget leilighetskompleks hvor han ikke hadde vært på årevis. Pasienten tenkte da mer på omgivelsene enn på underlaget og stoppet ikke opp slik han pleide å gjøre på grunn av Parkinsons sykdom».

Slik bedring kan naturligvis skyldes ekstra oppmerksomhet, men funnene samsvarer med forskning som tilsier at aktivisering og trening har en positiv innvirkning på pasienters funksjonsnivå og livskvalitet (4,12-16). Studentene oppdaget at pasientene gledet seg til hver gang. Videre sa de at det hadde vært spennende å delta i pasientenes rehabiliteringsprosess. Det ble fortalt om en pasient som var begynt å gå trapper i stedet for å ta heis fordi han var blitt så opptatt å være aktiv. Studentene tilskrev enhver forbedring av brukernes funksjonsnivå at de fikk trene med utgangspunkt i hva som var viktig for dem. Dette beskrev de som stimulerende for arbeidsmotivasjonen.

\section{Utfordringer: Veiledning}

Trass i omfattende informasjon var det lite samarbeid mellom studentene og sykepleierne i praksis. Som følge av mangel på utdannete sykepleiere begrenset samarbeidet seg til at studenter fikk hjelp til å finne egnete treningskan- 
didater, til målsettingssamtale og til midt- og sluttevaluering.

En måte høyskolene kan kvalitetssikre læringsstedene på, er å sikre at veiledningsressursene er optimale og praksis kunnskapsbasert før de sender studentene ut i praksis. Dette vil sikre gode praksisplasser for noen studenter, men antakeligvis også bidra til å øke mangelen på antall praksissteder på grunn av for få kvalifiserte sykepleiefaglige veiledere. Det beste vil nok være at lærere og sykepleiere i praksisfeltet samarbeider tettere om å lage praksismodeller som stimulerer til fagutvikling. Høyskolene bør jevnlig innkalle praksisveiledere til nettverksmøter der man sammen utarbeider gode veiledningsmodeller som sikrer god læring uavhengig av antall sykepleiere i praksisfeltet. Høyskolene bør også jobbe strategisk for å få myndighetene til å opprette stillinger for sykepleiere med pedagogisk- og fagutviklingskompetanse. Dette vil medføre at studentene opplever hjemmesykepleien som en god læringsarena og spennende arbeidsplass.

\section{Fagutvikling}

Studentene opplevde at fagutvikling nærmest var et ikke-eksisterende begrep. Sykepleierne stilte seg nærmest uforstående til at de hadde ansvar for fagutvikling. Det ble oppfattet som en byrde ingen snakket om. Disse erfaringene viser at faglig samarbeid må forankres høyt oppe i organisasjonen samtidig som man lager rom for fagutvikling på alle nivåer. For å få til reell fagutvikling må lederne etterspørre det, hvis ikke går alle ressursene til drift.

Sykepleiestudentene arbeidet selvstendig. De erfarte at læring er å oppdage og ble motiverte til å prøve ut flere nye metoder. Frihet til å velge selv er et sentralt behov hos mennesker $(17,18)$. Aktiviseringsmetodene bør derfor bestå av rammer som sykepleier og pasient kan jobbe innenfor. Kreativitet og det å få til noe på egen hånd vil styrke sykepleierens motivasjon og mestringsopplevelse. Studentene ble oppmerksomme på små behov hos pasientene som påvirket deres livskvalitet.

\section{Pasientmedvirkning}

Studentene viste til mange situasjoner hvor tidspress førte til at de ikke fikk aktivisert pasientene. Begrepet «tidspress» eller «ikke tid til» var godt innarbeidet på praksisstedet. Noen ganger ble det brukt for å legitimere at man gjorde oppgaver for pasienter i stedet for å tilrettelegge forholdene slik at de kunne gjøre mest mulig selv. «For eksempel var det satt av to personer til stell og forflytning av en slagpasient, men hjelpepleierne tok det stort sett alene og da uten å aktivisere pasienten. Pasienten var nærmest immobil i seng og rullestol. Målet var å bli fortest mulig ferdig». Studentene beskrev videre hvordan de gikk inn og aktiviserte pasienten. De ble overrasket over hvor lite trening som skulle til for å få pasienten på beina igjen. Flere studenter viste til situasjoner hvor det var tidsbesparende å aktivisere pasientene, og at valg om ikke å gjøre det er bygget på kortsiktige vurderinger om å spare tid her og nå. Ifølge Baltes (25) beskrives det som «overcare». Det kan krenke pasientene at de blir fratatt mulighet til selvbestemmelse og innflytelse på eget behandlingsopplegg. Dette viser til hvor viktig det er at sykepleiere deltar i helsepolitiske debatter og leser seg opp på fagstoff som omhandler pasientrettigheter og egne plikter. Sykepleietjenesten må være kjent med krav til pasientmedvirkning og forebyggende helsearbeid samt kunne argumentere for at tid avsettes til aktiviseringstiltak. Forslag fra studentene til forbedring av pasienttilbudet ble ofte avvist med tidspress. «Lite tid» begrunnet også nedprioritering av fagutvikling på bekostning av drift til tross for at det er en nedfelt plikt i Helsepersonelloven (20).

\section{Konsekvenser}

Prosjektet bidro til å holde fokus på sykepleie og motet opp hos studentene, på tross av problemer med å få fagpersoner til å delta. Vi kan konkludere med at studentene hadde god tid til å utføre treningsaktivitetene, og at aktiviseringsprosjektet var en godt egnet metode for å øke studentenes interesse for arbeid i hjemmesykepleien. I tillegg bidro prosjektet til rehabiliteringstankegang i sykepleierutdanningen og kvalitetsutvikling i sykepleien. Noen av de største utfordringene i hjemmebaserte tjenester er å utvikle arbeidsmodeller som tilfredsstiller dagens krav til fagutvikling, bidra til et kunnskapsbasert behandlingstilbud og til at sykepleierne er tilfredse med arbeidet sitt og stolte av det.

Prosjektet bidro til at studentene fikk et bevisst syn på aktivitetens betydning for å bevare egenomsorg, autonomi og verdighet i eldre år. Pasientene var meget godt fornøyde med å delta i prosjektet, de opplevde kvalitet i behandlingen og anbefalte det for andre pasienter. Både kartleggings- og treningsaktivitetene bidro til at studentene ble godt kjent med de gamle. Stor grad av faglig frihet økte sykepleiestudentenes motivasjon for å arbeide med eldre pasienter i hjemmesykepleien og med utvikling av helsetjenester i kommunehelsetjenesten.

\section{«Studentene ble godt kjent med de gamle.»}

Praksissted og høyskole bør avsettes mer tid til dialog eller nettverksmøter slik at man sammen kan bidra til utdanning av nysgjerrige og inspirerte sykepleiere som ønsker å utføre behandling og omsorg av god kvalitet. Dette er utfordrende i en verden der man fokuserer på drift og antall behandlete pasienter i praksis og studentproduksjon i høyskolene, men må likevel prioriteres for at resultatene skal bli gode for alle parter. IIII

\section{LITTERATUR}

B. Sykepleiestudenters erfaringer med å aktivisere eldre pasienter i hiemmesykepleien. Klinisk sykepleie 2009; 23 (2): 25-34.

2. Lov om helsetjeneste i kommunene. Lov av 19. nov. 1982. Sosialdepartementet, Oslo; sist endret 11. des. 2009

3. Standing M. Clinical Decision-making skills on the developmental journey from student to Registered Nurse: a longitudinal inquiry. J Adv Nurs 2007; 60 (3): 257-69.

. Fjørtoft A-K, Hanssen I. Hjemmesykepleien - et godt sted å være og lære for sykepleierstudenter? Norsk Tidsskrift for Sykepleieforskning 2006; 8 (3): 17-29.

5. Grendstad NM. Å lære er å oppdage. Oslo: Didakta Norsk Forlag; 1986.

6. IPLOS. Sosial- og helsedepartementet. Norge; 2009.

Mahoney FI, Barthel DW. Functional evaluation: the Barthel Index. Maryland State Medical Journal 1965; 14: 61-5.

8. Development of the World Health Organisation WHOQOL-BREF quality of life assessment. The WHOQOL Group. Psychol Med 1998; 28: 551-8.

9. Kvale K, Brinkmann S. Interview. København: Sage Publications. Inc.; 2008.

10. Helbostad JL. Fysisk trening av sykehjemsbeboere - har det noen hensikt? Tidsskr Nor Lægeforen 2005; 9 (125): 1195-7.

11. Feigenbaum MS, Pollock ML Prescription of resistance training for health and disease. Med Sci Sports Exerc. 1999; 31(1): 38-45.

12. Heyn $\mathrm{P}, \mathrm{Abreu} \mathrm{BC}, \mathrm{Ottenbacher} \mathrm{KJ}$. The effects of exercise training on elderly persons with cognitive impairment and dementia: a meta-analysis. Arch Phys Med Rehabil 2004; 85 (10): 1694-704.

13. Rydwik E, Frandin K, Akner G. Effects of physical training on physical performance in institutionalised elderly patients (70+) with multiple diagnoses. Age and Aging 2004; 33 (1): 13-23.

14. Ashworth NL, Chad KE, Harrison EL, Reeder BA, Marshall SC. Home versus center based physical activity programs in older adults. Cochrane Database of Systematic Reviews 2005; Issue 1. Art. No.: CD004017. Dol: 0.1002/14651858.CD004017.pub2.

15. Rasmussen B, Dolmer I, Delmar C. Et livsverdensperspektiv på rehabilitering. Klinisk Sykepleje 2008; 22 (4): 16-25.

16. Vass M, Avlund K, Siersma V, Hendriksen C. A feasible model for prevention of functional decline in older home-dwelling people - the GP role. A municipality-randomized intervention trial. Fam Pract 2008, Dec 12 (ePub ahead of print).

17. Wubbolding R, Brikell J. Counselling With Reality Therapy. United Kingdom: Winslow Press Ltd; 1999.

Glasser W. Choice Theory. New York: Harper Perennial; 1998

19. Baltes MM, Neumann E-M, Zank S. Maintenance and Rehabilitation of Independence in Old Age: An Intervention Program for Staff. American Psychological Assosiation 1994; 9 (2): 179-88.

20. Lov om helsepersonell, \$ 48. I. Lov av 2. juli 1999. Helse- og omsorgsdepartementet; Oslo; sist endret 19. jun. 2009. 